\title{
Active Teaching and Learning Strategies in Medical Education: Perception and Barriers among Faculty Members at Oman Medical College, Sohar/Bowshar Sultanate of Oman
}

\author{
Tıp Eğitiminde Aktif Öğrenme ve Öğretme Stratejileri: Umman Tıp Fakültesi \\ Ögretim Üyeleri Arasında Alg1 ve Engeller, Umman Sohar/Bowshar \\ Sultanlığ 1
}

\author{
Firdous Jahan ${ }^{l^{*}}$, Muhammad A A Siddiqui ${ }^{2}$, Maryam Abdul-Jabar Al-Khouri ${ }^{3}$, Alka Ahuja ${ }^{4}$, Mustafa Manhal Al- \\ Ward $^{3}$
}

\begin{abstract}
Background: Medical education is constantly evolving .It is more effective and long lasting if it is self-initiated and self-directed. Active teaching and learning strategy (ATLS) is the process by which a medical student independently, or in a group, identifies his or her learning objectives and actively seeks information necessary to achieve objectives. The study aims at identifying the faculty's use of active teaching and learning strategies and to explore the perceived barriers to its use in undergraduate teaching in the medical college. Methods: A cross sectional survey based study was carried out at Oman Medical College. All teaching faculties consented to participate were included in the study. Data was collected on self-administered questionnaire in which core elements were divided - Active teaching and learning strategies, barriers for active teaching and learning strategies and self-perception of the faculty about attributes of students. Statistical analysis was performed using SPSS (IBM SPSS Statistics 20.0). Data were expressed in frequencies, mean and percentages. Results: Total 60/ 74 faculty participated in the study; response rate is $81 \% ; 38.3 \%$ are male and $61.7 \%$ are female. Almost half of them are 40 50 years old and $50 \%$ faculty having total teaching experience $>10$ years. Majority of faculty are using ATLS as personal interest besides course requirements. Faculty's barriers for not using ATLS are heterogeneous group of students (34\%) and not being well prepared for that (41\%), too much preparation time $(40 \%)$, time constraint $(46.7 \%)$ and lack of learning resources $(41.6 \%)$. Conclusion: Study results concluded that faculty members are interested in active teaching and learning to improve their teaching and learn more about the use of active learning in the classroom. The main perceived barriers were lack of necessary class time, high comfort level with traditional lectures, and insufficient time to develop materials.

Keywords: Active teaching and learning strategy, medical education, small group, undergraduate students, faculty teaching
\end{abstract}

ÖZET

Giriş: Tıp eğitimi sürekli gelişmektedir, kendi kendine başladığında ve öz-yönetimli olduğunda daha etkin ve daha uzun ömürlüdür. Aktif öğrenme ve öğretme stratejileri (AÖÖS) tıp fakültesi öğrencisinin, bağımsız ya da bir grup içinde kendi öğrenme hedeflerini belirlediği ve etkin olarak bu hedeflere ulaşmak için gerekli bilgiye ulaştığı bir süreçtir. Bu çalışmanın amacı, aktif öğrenme ve öğretme stratejilerini fakültenin kullanım durumunu tanımlamak ve tıp fakültesinde mezuniyet öncesi uygulanmasıyla ilgili olarak algılanan engelleri araştırmaktır. Yöntem: Bu çalışma kesitsel araştırma deseninde Umman Tıp Fakültes'nde yürütüldü. Katılmaya onay veren tüm öğretim görevlileri çalışmaya alındı. Veriler kendi kendine uygulanan anket yöntemiyle toplandı. Anketin temel öğeleri; aktif öğrenme ve öğretme stratejileri, aktif öğrenme ve öğretme stratejilerinde engeller ve öğretim görevlilerinin öğrencilerin özelliklerine ilişkin algısı olmak üzere uygulandı. İstatistiksel analizler SPSS (IBM SPSS İstatistik 20.0) kullanılarak gerçekleştirildi. Veriler ortalama, yüzde, frekans olarak ifade edildi. Bulgular: Araştırmaya toplam 60/74 öğretim üyesi katıldı. Yanıtlanma oranı \% 81 olup; \% 38.3'ü erkek ve \% 61.7’i kadındır. Bunların neredeyse yarısını 40-50 yaşlarında olan ve toplam öğretim deneyimi 10 yıldan fazla olan öğretim görevlileri oluşturmaktadır. Öğretim görevlilerinin çoğunluğu kişisel ilgilerinin yanısıra ders gereksinimleri nedeniyle de AÖÖS kullanmaktadır. Öğretim üyelerinin AÖÖS kullanmamasındaki engeller heterojen öğrenci grubu, bunun için yeterince hazırlanmamış olmak (41\%), çok fazla hazırlık süresi gerekmesi (\% 40), zaman kısıtlaması (\% 46.7) ve öğrenme kaynaklarının yetersizliğidir (\% 41.6 ). Sonuç: Araştırma bulgularına göre öğretim üyelerinin, aktif öğrenme ve öğretimle kendi öğretim yöntemlerini geliştirmek için ilgilendikleri ve sınıfta aktif öğrenimin kullanımını daha fazla öğrenmek istedikleri sonucuna varılmıştır. Algılanan asıl engeller ise sınıfta gereken zamanın yetersiz olması, geleneksel ders anlatımının yüksek konfor düzeyi ve eğitim malzemeleri geliştirmek için zamanın yetersiz olmasidır.

Anahtar kelimeler:Aktif öğrenme ve öğretme stratejileri, Tıp eğitimi, Küçük grup, tıp öğrencisi, Öğretim üyesi eğitimi

Received /Geliş tarihi: 27.08.2015, Accepted/ Kabul tarihi: 07.10. 2015

${ }^{1}$ Oman Medical College Family Medicine Department, OMAN, ${ }^{2}$ School of Health Sciences Queen Margaret University,Edinburgh-UK, ${ }^{3}$ Oman Medical College,medical student,OMAN, ${ }^{4}$ Oman Medical College Department of Pharmacy,OMAN

* Address for Correspondence /Yazışma Adresi: Firdous Jahan, Oman Medical College Family Medicine Department, OMAN, Email:firdous@omc.edu.om

Jahan F, A A Siddiqui M, Al-Khouri MA, AhujaA, Manhal Al-Ward M. Active Teaching and Learning Strategies in Medical Education: Perception and Barriers among Faculty Members at Oman Medical College,Sohar/Bowshar Sultanate of Oman. TJFM\&PC, 2016;10(1):13-18.DOI: 10.5455/tjfmpc.198970 


\section{INTRODUCTION}

Teaching and learning become more effective and motivating when they are relevant to the solution of real life needs or problems for the learner. Medical students learn by receiving knowledge as well as by interpreting it actively based on their personal interest. It is more effective and long lasting if it is self-initiated and selfdirected ${ }^{1}$. Active learning is the process by which a medical student independently, or in a group, identifies his or her learning objectives and actively seeks information necessary to achieve objectives. As an active learner, medical student has a role defining his or her own learning outcomes. Medical educators and facilitators are expected to prepare students to be competent practitioners and meet the demands of evidence-based practice ${ }^{2}$. Teaching styles in medicine include traditional classroom learning which has faculty authority and visual learning. On the other hand, active learning strategies can address content and process objectives which include interpersonal, communication and problem-solving skills. There are greater expectations from students to communicate with patients to monitor their own learning and thus gain an experience of self-direction ${ }^{3}$.

Faculty participation as an educator plays an important and vital role in medical education. In active teaching and learning strategy teacher promotes learners' skills through active participation of the learner including small group work-based learning improving critical thinking of learners in a small group ${ }^{4}$. These strategies help medical students with problem solving and time management skills, towards reaching expected learning outcomes. Faculty involvement in active teaching and learning makes students more comfortable and provides a non-threating environment of self-directed learning; collaborative learning also encourages deeper understanding ${ }^{5,6}$.

These methods are adopted in different medical schools in accordance with their curriculum, resources and academic environment. However there are barriers of this style of learning and acceptance of personal responsibility for one's own progress. Student and faculty attitudes, too few faculty development opportunities, and the lack of an award system for teaching are major culture-based barriers. Environmental barriers, such as time limitations, the setting, and the physical space in which medical education takes place, and financial barriers, such as limited education budgets, also pose serious challenges for even the most committed teachers ${ }^{7}$. Although there are benefits of active learning, many teachers are reluctant to use active learning techniques. Many instructors have been taught in the traditional manner and are hesitant to adopt new techniques and undergo the anxiety that usually accompanies any kind of change or risk ${ }^{8,9}$.

Oman Medical College (OMC) is the first private Health Sciences College in Oman established in 2001. The College offers a 7 year MD (Doctor of Medicine) and a 5 year BPharm (Bachelor of Pharmacy) programs. The curriculum for MD and BPharm have been developed in Academic partnership with West Virginia University, USA and has been approved by the Ministry of Health and the Ministry of Higher Education. Teaching and learning strategies at OMC include integrated components of large class format, tutorials, lab work, problem based learning and clinical skills. The purpose of this study was to identify the faculty's use of active teaching and learning strategies and to explore the perceived barriers to its use in undergraduate teaching in the medical college.

\section{METHOD}

A cross sectional survey based study was carried out at Oman Medical College. All full time as well as part time teaching faculties of pharmacy, basic and clinical sciences consented to participate were included in the study. Data collection was carried out using a structured selfadministered questionnaire, especially designed for this study. The questionnaire was approved by the ethical review committee of Oman Medical College. Survey instrument was made after literature search was reviewed by and agreed on via several brain storming sessions and understanding so that the questionnaire would maximize the response rates. Questionnaire was distributed to faculty after being validated for readability, question design and length by a pilot study on 5 faculty members. Participants were enrolled after taking written informed consent. The principal investigator (PI) ensured uniformity and two trained research assistants assisted PI in data collection.

The questionnaire was designed comprising of three sections. The first section consists of demographic details of the participants. Section two contained questions regarding faculty members' current use of active learning, their perception of the technique, how often they use this technique and if the course or academic requirement is one's own initiative. Third section included the barriers for active teaching and learning. The last section of the questionnaire is about the self-perception of the faculty members. All questions had five response options (strongly agree, agree, neutral, disagree, and strongly disagree). Statistical analysis was performed using SPSS (IBM SPSS Statistics 20.0). Data was expressed in frequencies based on questionnaire responses calculated for all variables in numbers and percentages.

\section{RESULTS}

A total of 60 faculty members out of 74 participated in the study, response rate was $81 \%$. About one third of study participants were between 30-40 years old nearly half of them $(45 \%)$ were between $40-50$ years age group. $38 \%$ were male and $62 \%$ were female. Fifty percent of the faculty had teaching experience of more than 10 years, 41.7\% faculty members had formal training in medical education. Table 1shows general characteristic of study participants. 


\begin{tabular}{|c|c|c|}
\hline & Frequency & Percent \\
\hline \multicolumn{3}{|l|}{ Age } \\
\hline $30-40$ & 20 & 33.3 \\
\hline $40-50$ & 27 & 45.0 \\
\hline $50-60$ & 10 & 16.7 \\
\hline$>60$ & 3 & 5.0 \\
\hline \multicolumn{3}{|l|}{ Gender } \\
\hline Male & 23 & 38.0 \\
\hline Female & 37 & 62.0 \\
\hline \multicolumn{3}{|l|}{ Total teaching experience } \\
\hline$<5$ & 12 & 20.0 \\
\hline $5-10$ & 18 & 30.0 \\
\hline$>10$ & 30 & 50.0 \\
\hline \multicolumn{3}{|l|}{ Designation/ Position } \\
\hline GP & 1 & 1.7 \\
\hline Family Physician & 4 & 6.7 \\
\hline Specialist & 7 & 11.7 \\
\hline Consultant & 2 & 3.3 \\
\hline Basic Science & 17 & 28.3 \\
\hline Clinical Instructor & 4 & 6.7 \\
\hline Others & 25 & 41.7 \\
\hline \multicolumn{3}{|l|}{ Highest Degree } \\
\hline MD & 17 & 28.3 \\
\hline MRCGP & 3 & 5.0 \\
\hline Bachelor & 7 & 11.7 \\
\hline $\mathrm{PhD}$ & 13 & 21.7 \\
\hline MPhil & 1 & 1.7 \\
\hline Masters & 12 & 20.0 \\
\hline Others & 7 & 11.7 \\
\hline \multicolumn{3}{|l|}{ Teaching } \\
\hline Medical Students & 33 & 55.0 \\
\hline Pharmacy Student & 9 & 15.0 \\
\hline Medical \& Pharmacy Student & 15 & 25.0 \\
\hline Medical, Pharmacy and others & 3 & 5.0 \\
\hline \multicolumn{3}{|l|}{ Medical Education Training } \\
\hline Yes & 25 & 41.7 \\
\hline No & 35 & 58.3 \\
\hline
\end{tabular}

The perceived barriers for ATLS lack of training (70\%), hands on training in large class $(70 \%)$, limited resources $(65 \%)$, more work load (61.7\%), students background and time constraint $(53.3 \%)$ and limited incentives for faculty (45\%) (Fig 1).

S Disagree $\square$ Disagree $n$ Neutral $n$ Agree $\square$ S Agree

Perceptual and...18,3 36,7 23,321,70

Cultural and Language... $15 \quad 30 \quad 15 \quad 36,73 \| 3$

Physical and...11,731,7 $36,7 \quad 200$

Students prefer...13,3 $45 \quad 1521,75$

Fear of negative student...8,3 $51,7 \quad 21,718,8)$

It demands more work..3,35 20 46,7

Students are more... $15 \quad 3013,3 \quad 35 \quad 6,7$

Motivation and...11,7 30 13,3 36,7 8, B

Lack of needed... $51515 \quad 46,7 \quad 18,3$

Time constrain $8,31,716,7 \quad 45 \quad 8, B$

Peers don't want to...8,328,3 28,3 26,78, B

Lack of administrative..6,728,3 28,3 2511,7

Involves risks of failure...16,728,3 $30 \quad 250$

Students background 3, $33,3 \quad 20 \quad 43,3 \quad 10$

Different levels of..1, $11,728,3 \quad 41,7 \quad 6,7$

This is expensive and... $10 \quad 30 \quad 30 \quad 25$ 5

Fear of change/ failure 11,7 43,3 25200

A limited... $1020 \quad 25 \quad 26,718$,

Teacher's inability to... $10 \quad 36,7 \quad 21,726,7 \mathbf{5}$

Hands on experience is...313,715 56,7 13,

Curriculum is not aligned...13,336,7 23,318,8,3

$\begin{array}{llll}\text { The course content is...8,3 } & 45 & 25 & 2017\end{array}$

New curriculum needs... $8,36,7 \quad 56,7 \quad 13, \mathbf{B}$

Figure 1. Barriers for active teaching and learning strategies

Table 2 shows participants' responses regarding active teaching and learning strategies. More than half (56.7\%) of faculty members frequently use interactive lecture method and more than two third $(76.7 \%)$ regularly conducting discussion using power point or transparencies. While more than half sometime use problem based and problem solving teaching and learning strategies.

Participants were asked multiple questions regarding characteristics/attributes of students, issues having direct impact on faculty and pedagogical issues. Half of the participant's believe that students have no knowledge of active learning and are unwilling to follow active learning as well. In the questionnaire, participants were asked about issues having direct impact on faculty members using five 
responses. Disagreement was highest (41.7\%) for the statements suggesting lack of professional maturity of the faculty member and $53.3 \%$ for the statements suggesting that teacher has less control. In other questions regarding pedagogical issues, $56.7 \%$ agreed that class rooms are not designed for active learning and $55 \%$ think class size is a barrier for active learning (Table 3)

Table 2. Active teaching and learning strategies - n (\%)

\begin{tabular}{|c|c|c|c|c|c|}
\hline & \multicolumn{3}{|c|}{ How often do you use? } & \multicolumn{2}{|c|}{$\begin{array}{c}\text { Use of strategies: course requirement or own } \\
\text { initiative? }\end{array}$} \\
\hline & Never & Sometimes & Often & Course requirement & Personal interest \\
\hline $\begin{array}{l}\begin{array}{l}\text { Discussions using } \\
\text { transparencies }\end{array}\end{array}$ & $4(6.7)$ & $10(16.7)$ & $46(76.7)$ & $40(66.7)$ & $20(33.3)$ \\
\hline Seminar & $21(35)$ & $25(41.7)$ & $14(23.3)$ & $29(48.3)$ & $31(51.7)$ \\
\hline Quizzes/Exams & $2(3.3)$ & $17(28.3)$ & $41(68.3)$ & $47(78.3)$ & $13(21.7)$ \\
\hline The "one minute preceptor" model & $27(45)$ & $21(35)$ & $12(20)$ & $29(48.3)$ & $31(51.7)$ \\
\hline Peer assisted teaching & $20(33.3)$ & $29(48.3)$ & $11(18.3)$ & $26(43.3)$ & $34(56.7)$ \\
\hline Role playing/simulation/games & $23(38.3)$ & $28(46.7)$ & $9(15)$ & $20(33.3)$ & $40(66.7)$ \\
\hline Panel discussion & $24(40)$ & $29(48.3)$ & $7(11.7)$ & $26(43.3)$ & $34(56.7)$ \\
\hline Case study-scenario based & $9(15)$ & $30(50)$ & $21(35)$ & $30(50)$ & $30(50)$ \\
\hline Use of videos, audios, animations, pictures & $2(3.3)$ & $33(55)$ & $25(41.7)$ & $19(31.7)$ & $41(68.3)$ \\
\hline Team-based learning & $21(35)$ & $21(35)$ & $18(30)$ & $25(41.7)$ & $35(58.3)$ \\
\hline Research reports/study/critical analysis & $16(26.7)$ & $32(53.3)$ & $12(20)$ & $32(53.3)$ & $28(46.7)$ \\
\hline $\begin{array}{l}\text { Reflective journaling and portfolio } \\
\text { development }\end{array}$ & $27(45)$ & $20(33.3)$ & $13(21.7)$ & $26(43.3)$ & $34(56.7)$ \\
\hline Problem based and problem solving & $7(11.7)$ & $35(58.3)$ & $18(30)$ & $33(55)$ & $27(45)$ \\
\hline Patient centered clinical presentation & $22(36.7)$ & $23(38.3)$ & $15(25)$ & $36(60)$ & $24(40)$ \\
\hline Demonstration/hands on practice skill & $12(20)$ & $25(41.7)$ & $23(38.3)$ & $34(56.7)$ & $26(43.3)$ \\
\hline Small group work & $6(10)$ & $27(45)$ & $27(45)$ & $35(58.3)$ & $25(41.7)$ \\
\hline $\begin{array}{l}\text { Use of devices, instruments (NGT, catheter, } \\
\text { surgical instrument...) }\end{array}$ & $30(50)$ & $17(28.3)$ & $13(21.7)$ & $33(55)$ & $27(45)$ \\
\hline Visits to sites & $35(58.3)$ & $19(31.7)$ & $6(10)$ & $31(51.7)$ & $29(48.3)$ \\
\hline $\begin{array}{l}\text { Involvement of students in awareness } \\
\text { campaign }\end{array}$ & $19(31.7)$ & $34(56.7)$ & $7(11.6)$ & $24(40)$ & $36(60)$ \\
\hline
\end{tabular}

Table 3. Self-perception of the faculty and its influence on their readiness - n (\%)

\begin{tabular}{|c|c|c|c|c|c|}
\hline & S Disagree & Disagree & Neutral & Agree & S Agree \\
\hline \multicolumn{6}{|l|}{ Characteristics/attributes of students } \\
\hline Students have no knowledge of active learning & $4(6.7)$ & $29(48.3)$ & $10(16.7)$ & $15(25)$ & $2(3.3)$ \\
\hline $\begin{array}{l}\text { Active learning compromised as students are not well } \\
\text { prepared }\end{array}$ & $1(1.7)$ & $23(38.3)$ & $11(18.3)$ & $23(38.3)$ & $2(3,3)$ \\
\hline Students unwilling to follow this method & $4(6.7)$ & $30(50)$ & $14(23.3)$ & $9(15)$ & $3(5)$ \\
\hline Heterogeneous group of students makes it difficult & $1(1.7)$ & $23(38.3)$ & $15(25)$ & $16(26.7)$ & $5(8.3)$ \\
\hline Lack of maturity & $2(3.3)$ & $20(33.3)$ & $21(35)$ & $15(25)$ & $2(3.3)$ \\
\hline Expectations of students about teaching methodologies & 0 & $17(28.3)$ & $27(45)$ & $15(25)$ & $1(1.7)$ \\
\hline \multicolumn{6}{|l|}{ Issues having direct impact on faculty } \\
\hline Too much preparation time & $4(6.7)$ & $19(31.7)$ & $13(21.7)$ & $23(38.3)$ & $1(1.7)$ \\
\hline Teacher has less control & $5(8.3)$ & $32(53.3)$ & $9(15)$ & $14(23.3)$ & 0 \\
\hline Perception of colleagues & $3(5)$ & $20(34)$ & $20(33.3)$ & $16(26.7)$ & 0 \\
\hline Risk of poor student evaluations or ratings & $4(6.7)$ & $25(41.7)$ & $12(20)$ & $18(30)$ & $1(1.7)$ \\
\hline Lack of professional maturity of faculty member & $5(8.3)$ & $25(41.7)$ & $15(25)$ & $12(20)$ & $3(5)$ \\
\hline Faculty members do not know how to do it & $4(6.7)$ & $24(40)$ & $18(30)$ & $12(20)$ & $2(3.3)$ \\
\hline \multicolumn{6}{|l|}{ Pedagogical issues } \\
\hline Not enough learning resources are available & $5(8.3)$ & $13(21.7)$ & $17(28.3)$ & $23(38.3)$ & $2(3.3)$ \\
\hline Class rooms not designed for active learning & $2(3.3)$ & $14(23.3)$ & $7(11.7)$ & $34(56.7)$ & $3(5)$ \\
\hline Takes too much time and less content is covered & $2(3.3)$ & $19(31.7)$ & $11(18.3)$ & $24(40)$ & $4(6.7)$ \\
\hline Student assessment is difficult & $3(5)$ & $29(48.3)$ & $12(20)$ & $13(21.7)$ & $3(5)$ \\
\hline Class size is an impediment to active learning & $3(5)$ & $8(13.3)$ & $9(15)$ & $33(55)$ & $7(11.7)$ \\
\hline Hard to predict the learning outcomes & $2(3.3)$ & $25(41.7)$ & $11(18.3)$ & $21(35)$ & $1(1.7)$ \\
\hline Quality control is difficult to ensure & $2(3.3)$ & $24(40)$ & $17(28.3)$ & $16(26.7)$ & $1(1.7)$ \\
\hline
\end{tabular}




\section{DISCUSSION}

Active learning strategies require students to participate and think about what they are doing. Small group learning provides more active learning, better retention, higher satisfaction, and facilitates development of problem-solving and team-working abilities ${ }^{10}$. In this study most of the faculty members were using ATLS as course requirement and some over personal interest. Previous studies reported that small group education provides best learning environment for students ${ }^{11,12}$. Traditional teaching methods should be transformed to improve learning experiences and facilitate lifelong learning. Recent studies suggested that small group teaching and learning is preferred by students which help them improve in-depth learning, enhancing understanding with positive outcome ${ }^{13,14}$.

Teachers are responsible for designing learning experiences and supporting learning on multiple levels. This study results has shown that the faculty self-perception regarding their readiness is mainly that students are not well prepared, the method requires has a lot of preparation time and heterogeneous group makes it difficult ${ }^{15}$.

In this study faculty also mentioned that ATLS is a pedagogical issue; the most important factors are nonavailability of learning resources, time constraint and class size. However, ATLS help students become more aware of their own responsibility for learning and facilitate their development of becoming self-directed, lifelong learners. Faculty and students perception of ATLS effectiveness is published in literature ${ }^{16}$. Traditional forms of teaching is effective when the incorporation of new ideas with traditional practices will result in more effective forms of teacher-student interactions. Lectures are good for some conceptual learning but small group activity is the best ${ }^{17,18}$. The highest area of agreement in this study was when the participants admitted that the use of ATLS improves learning but requires great deal of effort. Small group case based learning method makes learning interesting, students' communication and interpersonal skills are enhanced ${ }^{19,20}$. Historical perspective reveals that medical faculty need to make changes in their teaching methodologies. Literature supports the fact that medical faculty has positive attitude towards ATLS ${ }^{21}$. Our faculty showed the strategies mainly used for teaching and learning in small groups but they have least interest in quiz and transparencies. Small group teaching offers active participation of learners, increase the teamwork ability, retention of knowledge, enhance transfer of concepts to new problems, increase student interest, and improve the self-directed learning and critical skills ${ }^{22,23}$.

Half of our study population are experienced teachers and nearly half of them had formal training in medical education. The perceived barriers for ATLS was lack of training, limited resources, work load, students' back ground and time constraint and limited incentives for faculty. Literature also reports same findings about the main barriers that prevent faculty members from adopting active learning strategies in the professional classroom. ATLS is a student-centered learning, which is characterized by active participation and autonomous learning ${ }^{24,25}$.

Strategies should be used to create a faculty development program to train teachers how to create and implement active learning in their classrooms. This also requires hands-on training in material development and classroom management, peer feedback on initial implementations, and assessment of the learning strategy ${ }^{26}$.

\section{CONCLUSION}

Study results concluded that faculty members are interested in active teaching and learning to improve their teaching and learn more about the use of active learning in the classroom. This study served the important function of determining the main barriers that prevent faculty members from adopting active learning strategies in the professional classroom. In particular, it showed that the main perceived barriers were a lack of necessary class time, a high comfort level with traditional lectures, and insufficient time to develop materials. These results will be useful to create a faculty development program that trains teachers for ATLS.

Study Limitation: This study is conducted in one medical college so the result cannot be generalized. Further research is required at different medical colleges at different level in a larger sample size.

Disclosure Statement: Authors declared no conflict of interest and no funding was received for this work.

\section{REFERENCES}

1.Armbruster P, Patel M, Johnson E, Weiss M. Active learning and student-centered pedagogy improve student attitudes and performance in Introductory Biology. CBE Life Sci Educ 2009; 8: 203-213.

2.Carvalho $\mathrm{H}$, West CA. Voluntary participation in an active learning exercise leads to a better understanding of physiology. Adv Physiol Educ 2011; 35: 53-58.

3.Cavanagh M. Students' experiences of active engagement through cooperative learning activities in lectures. Active Learn Higher Educ 2011; 12: 23-33.

4.Ernst $\mathrm{H}$, Colthorpe $\mathrm{K}$. The efficacy of interactive lecturing for students with diverse science backgrounds. Adv Physiol Educ 2007; 31: 41-44.

5.Lom B. Classroom activities: simple strategies to incorporate student centered activities within undergraduate science lectures. J Undergrad Neurosci Educ 2012; 11: A64-A71.

6.Lujan HL, DiCarlo SE. Too much teaching, not enough learning: what is the solution? Adv Physiol Educ 2006; 30: $17-22$. 
7.DaRosa DA, Skeff K, Friedland JA, Coburn M, Cox S, Pollart S, O'connell M, Smith S. Barriers to effective teaching Acad Med. 2011 Apr; 86(4):453-9. doi: 10.1097/ACM.0b013e31820defbe.

8.Michael K. Where's the evidence that active learning works? Adv Physiol Educ 2006; 30: 159-167.

9.Leipzig R, Hyer K, Ek , Wallenstein S, Vezina M, Fairchild S, Cassel C, Howe J. Attitudes toward working on interdisciplinary healthcare teams: a comparison by discipline. Journal of the American Geriatrics Society 2002; 50: 1141-1148.

10.Margery D. Problem based learning, Centre for Medical Education, University of Dundee, 2005:4-17.

11.Meo SA, Shahabuddin S, Al Masri AA, Ahmed SM, Aqil M, Anwer MA, Al-Drees AM. Comparison of the impact of power point and chalkboard in undergraduate medical teaching: an evidence based study. J Coll Physicians Surg Pak 2013; 23(1):47-50.

12.Crosby J, Hesketh EA. Developing the teaching instinct: Small group learning. Med Teach. 2004; 26(1):16-19.

13.Meo SA. Giving feedback in medical teaching, A case of lung function laboratory / Spirometry. J Coll Physicians Surg Pak. 2013; 23(1):86-89.

14.Abubakir M S, Nazar P S, Ali A D, Namir G AT, Tariq $\mathrm{S}$ AH. A qualitative assessment of faculty perspectives of small group teaching experience in Iraq. BMC Medical Education 2015; 15:19

15.Minhas PS, Ghosh A, Swanzy L. The effects of passive and active learning on student preference and performance in an undergraduate basic science course. Anat Sci Educ 2012; 5: 200-207.

16.Swapnil P, Chinmay S. Faculty perceptions of the strengths, weaknesses and future prospects of the current medical undergraduate experimental physiology curriculum in Gujarat, India. Indian J Physiol Pharmacol 2015; 59(1):109-116.

17.Kowalczyk N, Hackworth R, Case-Smith J. Perceptions of the use of critical thinking teaching methods. Radiol Technol. 2012; 83(3):226-36.

18.Knight JK, Wood WB. Teaching more by lecturing less. Cell Biol Educ2005; 4: 298-310.

19.Archana A, Dharwadkar, Shruti M. Undergraduate students' and faculty perceptions on small group learning in biochemistry. International Journal of Scientific Research and Education. 2015;3(2):2917-2923

20.Minhas PS, Ghosh A, Swanzy L. The effects of passive and active learning on student preference and performance in an undergraduate basic science course. Anat Sci Educ 2012; 5: 200-207.

21.Katie J. Suda MS, Gillian C. Bell, Andrea S. Franks .Faculty and Student Perceptions of Effective Study Strategies and Materials. American Journal of Pharmaceutical Education 2011; 75 (10).

22.Desselle BC, English R, Hescock G, Hauser A, Roy M, Yang T, Chauvin SW. Evaluation of a Faculty Development Program aimed at increasing residents' active learning in lectures. J Grad Med Educ 2012; 4: 516-520.
23.Sultan AM. Basic steps in establishing effective small group teaching sessions in medical schools. Pak J Med Sci. 2013; 29(4): 1071-1076.

24.Helena F. The Use of Small Group Tutorials as an Educational Strategy in Medical Education. International Journal of Higher Education, 2015; 4(2).

25.Cynthia JM, Michael JM. A comparison of professionallevel faculty and student perceptions of active learning: its current use, effectiveness, and barriers. Adv Physiol Educ 2014; 38: 246-252

26.Graffam B. Active learning in medical education: strategies for beginning implementation. Med Teach. 2007; 29(1):38-42. 